\title{
Pengaruh E-Service Quality dan E-Recovery Service Quality Terhadap E-Loyalty Pada Pelanggan PT. X Fitur PT. X
}

\section{Zenda Eka Brilian, Ratih Tresnati, Nina Maharani}

Prodi Manajemen, Fakultas Ekonomi dan Bisnis, Universitas Islam Bandung, Indonesia.

*zendabrilian91@gmail.com, ratihtresnati27@gmail.com, maharani.nina09@gmail.com

\begin{abstract}
This study aims to determine how much influence E-Service Quality and E-Recovery Service Quality have on E-Loyalty on PT. X customers with PT. X features. This researcher uses a survey method. With the sampling method, namely the purposive sampling technique aimed at PT. X Features PT. X customers in Bandung City by distributing questionnaires to 100 respondents. The results of this study partially and simultaneously found that E-Service Quality and E-Recovery Service Quality have a significant positive effect on E-Loyalty on PT. X customers with PT. X features.
\end{abstract}

Keywords: E-Service Quality, E-Recovery Service Quality, E-Loyalty.

Abstrak. Penelitian ini bertujuan untuk mengetahui seberapa besar pengaruh E-Service Quality dan E-Recovery Service Quality terhadap E-Loyalty pada pelanggan PT. X dengan fitur PT. X. Peneliti ini menggunakan metode survey. Dengan metode pengambilan sampel yaitu dengan teknik purposive sampling yang ditujukan kepada pelanggan PT. X Fitur PT. X di Kota Bandung dengan menyebarkan kuesioner kepada 100 responden. Hasil penelitian ini secara parsial dan simultan menemukan bahwa E-Service Quality dan E-Recovery Service Quality berpengaruh positif signifikan terhadap E-Loyalty pada pelanggan PT. X dengan fitur PT. X

Kata Kunci: E-Service Quality, E-Recovery Service Quality, E-Loyalty. 


\section{A. Pendahuluan}

Akhir - akhir ini teknologi sedang berkembang pesat, dan banyak hal yang terjadi di dunia maya saat ini. Membawa banyak manfaat dan memudahkan semua aktivitas misalnya seperti berbelanja tidak perlu pergi ke toko bisa melalui web site itu sendiri atau misalnya segala sesuatu daerah tertentu yang ingin dikunjungi bisa di tempuh dalam waktu yang sangat singkat serta kendaraan yang memadai. Tiap orang pasti memerlukan transportasi buat berpergian, maka itu timbul beberapa pengembangan teknologi pada bidang transportasi. (Sumber: Kompasiana, 2019)

Jasa transportasi online berbasis aplikasi yaitu sistem elektronik untuk penghubung antara pengemudi dengan konsumen jasa. Penyedia software memiliki peran penting pada berhasilnya sistem jasa transportasi online berbasis aplikasi online. Pengguna jasa transportasi online berbasis aplikasi biasanya masyarakat yang membutuhkan jasa transportasi yang nyaman. (Sumber: Pratama, Geistiar Yoga, dan Aminah Suradi, Diponegoro Law Journal, 2016:2).

PT. X merupakan badan usaha yang bidang usahanya berfokus pada industri jasa transportasi online. PT. X memulai perjalanannya pada tahun 2010. PT. X saat ini telah berkembang menjadi platform teknologi yang dapat menyediakan berbagai fitur seperti transportasi (GoRide, GoCar), logistik (GoShop), pembayaran elektronik (GoPay), pesan-antar makanan (PT. X ), jemput-antar paket (GoSend), pembelian pulsa (GoPulsa) dan berbagai Fitur lainnnya. (Sumber: PT. X Indonesia, 2020)

Kini Fitur yang di pilih adalah jasa pesan-antar makanan (PT. X ). Fitur PT. X dibuat untuk memudahkan konsumen dalam memesan makanan tanpa harus datang ke restoran atau tempat penjual makanan. Fitur PT. X sangat efektif terutama di kota besar. (Sumber: PT. PT. $\mathrm{X}$ Indonesia, 2020).

Pada dasarnya E-Service Quality dan E-Recovery Service Quality dapat menjadikan pelanggan loyal juga dikatakan oleh sejumlah pakar atau para ahli, diantaranya: Zehir \& Narcikara (2016:440) menjelaskan bahwa untuk mengetahui loyalitas pelanggan dapat didasarkan pada kualitas pelayanan, penanganan masalah, keuntungan dan nilai dari pelayanan yang diberikan kepada pelanggan.

Sedangkan fakta di lapangan menyatakan sebaliknya, bahwa E-Service Quality dan ERecovery Service Quality yang diterapkan oleh PT. X Fitur PT. X belum efektif sehingga membuat para pelanggan menjadi tidak loyal. Berdasarkan data pengguna PT. X pada tahun 2020 .

Berdasarkan hal itu peneliti meneliti mengenai judul "Pengaruh E-Service Quality dan E-Recovery Service Quality terhadap E-Loyalty Pada Pelanggan PT. X Fitur PT. X ". Selanjutnya, tujuan dalam penelitian ini, yaitu:

1. Untuk mengetahui Penerapan E-Service Quality pada PT. X Fitur PT. X .

2. Untuk mengetahui E-Recovery Service Quality pada PT. X Fitur PT. X .

3. Untuk mengetahui E-Loyalty pada pelanggan PT. X Fitur PT. X .

4. Untuk mengetahui seberapa besar pengaruh E-Service Quality terhadap E-loyalty pada pelanggan PT. X Fitur PT. X .

5. Untuk mengetahui seberapa besar pengaruh E-Recovery Service Quality terhadap Eloyalty pada pelanggan PT. X Fitur PT. X .

6. Untuk mengetahui seberapa besar pengaruh E-Service Quality dan E-Recovery Service Quality terhadap E-loyalty pada pelanggan PT. X Fitur PT. X.

\section{B. Metodologi Penelitian}

Metode yang digunakan adalah metode survey dan teknik penarikan sample adalah purposive sampling. Jenis penelitian ini adalah deskriptif dan verifikatif kuantitatif. Populasi dalam penelitian ini adalah pelanggan PT. X Fitur PT. X di Kota Bandung. Sample yang diambil adalah 100 orang responden. Metode analisis data yang digunakan adalah analisis linear berganda. Dalam penelitian ini menggunakan variabel independent yaitu E-Service Quality dan E-Recovery Service Quality dengan variabel dependen yaitu E-Loyalty yang diuraikan sebagai berikut: 


\section{E-Service Quality}

Menurut Parasuranman, Zeithaml, dan Malhotra (2005:217) E-Service Quality adalah kemampuan situs website memberikan layanan pembelian, dan pengiriman yang efesien. Adapun terdapat 4 dimensi dalam E-Service Quality menurut Parasuranman, Zeithaml, dan Malhotra (2005:220):

1. Efficiency adalah kemudahan serta kecepatan dalam mengakses web.

2. Fulfillment adalah kemampuan perusahaan dalam memberikan janji melalui website.

3. System Availability adalah semua fungsi teknik yang tersedia dapat berjalan dengan efektif.

4. Privacy adalah kemampuan perusahaan untuk melindungi informasi data pribadi pelangganya.

\section{E-Recovery Service Quality}

E-Recovery Service Quality adalah servis yang diberikan oleh perusahaan terhadap pelangganya ketika terjadi masalah atau pelangganya tidak puas dengan layanan yang diberikan secara elektronik (Anton Tirta Komara 2014). Menurut Parasuranman, Zeithaml, dan Malhotra (2005:220) ada 3 dimensi E-Recovery Service Quality, antara lain:

1. Responsiveness adalah menanggapi permasalahan yang dirasakan oleh pelangga melalui website.

2. Compensation adalah perusahaan mampu memberi ganti rugi atas permasalahan yang dirasakan oleh pelangganya.

3. Contact adalah terdapat bantuan dengan telepon maupun komunikasi lainnya.

\section{E-Loyalty}

Menurut Winnie (2014:391) e-loyalty yaitu perilaku yang bermanfaat bagi pelanggan dari sebuah usaha elektronik untuk melakukan pembelian berulang. Menurut Winnie (2014:391), mengkonsepkan $e$-loyalty ke dalam 3 dimensi, antara lain:

1. Word of Mouth adalah terkait membagikan informasi, seperti argumen dan pengetahuan masa lalu yang nanti akan merekomendasi atau tidak suatu produk ataupun jasa.

2. Future Purchase Intention adalah terkait maksud pelanggan untuk melakukan pembelian di masa yang akan datang.

3. Complaining Behavior adalah terkait pada reaksi negatif yang dialami saat pelanggan tidak puas dengan produk atau jasa.

\section{Hasil Penelitian dan Pembahasan}

Gambar 1. Garis Kontinum E-Service Quality (X1)

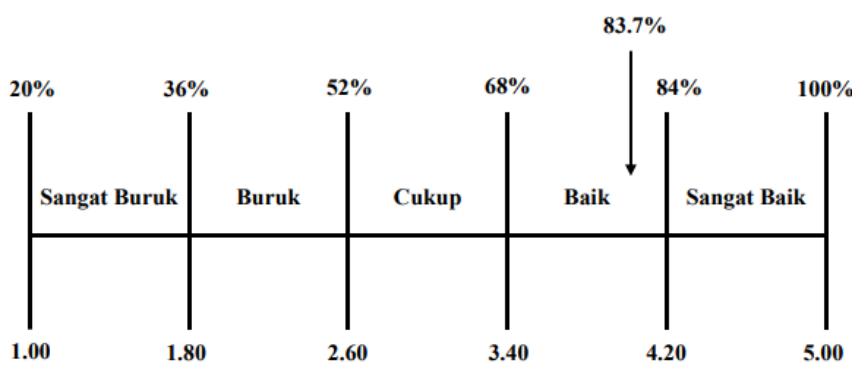

Hasil garis kontinum diatas bahwa ulasan responden mengenai variabel E-Service Quality mendapatkan rata-rata skor dari semua indikator yaitu $4.19(83.7 \%)$ dan masuk dalam klarifikasi baik karena dalam interval 3.40 - 4.20. Artinya secara keseluruhan responden menilai E-Service Quality pada PT. X Fitur PT. X dirasakan baik. 
Gambar 2. Garis Kontinum E-Recovery Service Quality (X2)

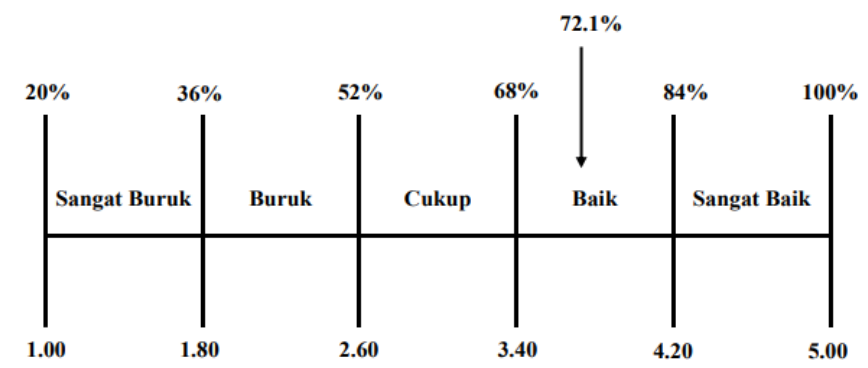

Hasil garis kontinum di atas bahwa ulasan responden mengenai variabel E-Recovery Service Quality mendapatkan rata-rata skor dari semua indikator yaitu $3.60(72.1 \%)$ dan masuk pada klarifikasi baik karena dalam interval 3.40 - 4.20. Artinya secara keseluruhan responden menilai E-Recovery Service Quality pada PT. X Fitur PT. X dirasakan baik.

Gambar 3. Garis Kontinum E-Loyalty $(Y)$

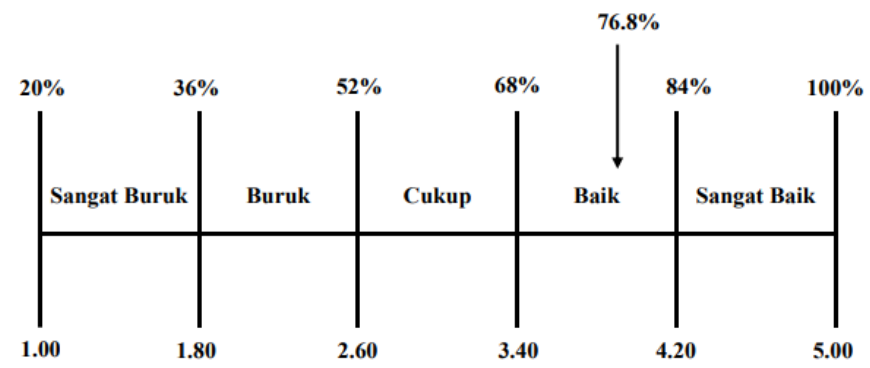

Hasil garis kontinum diatas bahwa ulasan responden mengenai variabel E-Loyalty mendapatkan rata-rata skor dari semua indikator yaitu 3.84 (76.8\%) dan masuk pada klarifikasi baik karena dalam interval 3.40 - 4.20. Artinya secara keseluruhan responden menilai E-Loyalty pada pelanggan PT. X Fitur PT. X dirasakan baik.

\section{Pengujian Hipotesis}

Tabel 1. Coefficients

\begin{tabular}{|c|c|c|c|c|c|c|}
\hline \multicolumn{7}{|c|}{ Coefficients $^{a}$} \\
\hline & & \multicolumn{2}{|c|}{$\begin{array}{l}\text { Unstandardized } \\
\text { Coefficients }\end{array}$} & \multirow{2}{*}{$\begin{array}{c}\text { Standardized } \\
\text { Coefficients } \\
\text { Beta } \\
\end{array}$} & \multirow[b]{2}{*}{$t$} & \multirow[b]{2}{*}{ Sig. } \\
\hline \multicolumn{2}{|c|}{ Model } & B & Std. Error & & & \\
\hline \multirow[t]{3}{*}{1} & (Constant) & 1.275 & .957 & & 1.332 & 186 \\
\hline & E-Service Quality (X1) & 377 & .053 & .537 & 7.084 & .000 \\
\hline & $\begin{array}{l}\text { E-Recovery Service } \\
\text { Quality (X2) }\end{array}$ & .428 & .093 & .350 & 4.615 & .000 \\
\hline
\end{tabular}

Dilihat pada hasil pengujian diatas diketahui bahwa nilai uji-t variabel E-Service Quality menghasilkan 7.084> 1,984 dengan probabilitas $0.000<0.05$. Dengan ini terdapat pengaruh secara parsial antara E-Service Quality terhadap E-Loyalty di PT. X Fitur PT. X. Selanjutnya diketahui bahwa nilai uji-t variabel $E$ - Recovery Service Quality menghasilkan sebesar 4.615 thitung $>$ ttabel karena 4.615> 1,984 dengan probabilitas $0.000<0.05$. Dengan ini terdapat pengaruh secara parsial antara E-Recovery Service Quality terhadap E-Loyalty di PT. X Fitur PT. X. 
Tabel 2. Anova

\begin{tabular}{|c|c|c|c|c|c|c|}
\hline \multicolumn{7}{|c|}{ ANOVA $^{a}$} \\
\hline \multicolumn{2}{|c|}{ Model } & Sum of Squares & df & Mean Square & $\mathrm{F}$ & Sig. \\
\hline \multirow[t]{3}{*}{1} & Regression & 524.685 & 2 & 262.342 & 80.453 & $.000^{\mathrm{b}}$ \\
\hline & Residual & 316.300 & 97 & 3.261 & & \\
\hline & Total & 840.984 & 99 & & & \\
\hline
\end{tabular}

Dilihat dari hasil pengujian diatas bahwa nilai Fhitung $(80,453)$ lebih besar dari pada Ftabel $(3,09)$ di tingkat kekeliruan 5\% $(\alpha=0,05)$. Maka dari itu variabel E-Service Quality dan E-Recovery Service Quality secara simultan berpengaruh pada variabel E-Loyalty.

\section{Kesimpulan}

Berdasarkan hasil penelitian di atas, maka peneliti mengambil kesimpulan, diantaranya:

1. Penerapan E-Service Quality yang dimiliki oleh PT. X Fitur PT. X dianggap sudah baik oleh pelanggan dalam memberikan layanan elektronik karena telah menerapkan 4 dimensi dari E-Service Quality yang berkualitas.

2. E-Recovery Service Quality yang dimiliki oleh PT. X Fitur PT. X dianggap sudah baik oleh pelanggan dalam memberikan pemulihan layanan elektronik, Ada beberapa hal yang dirasa kurang oleh pelanggan seperti mengenai kompensasi yang di berikan oleh PT. X Fitur PT. X belum maksimal kepada pelanggan yang merasa produknya tidak sesuai dengan pesanannya.

3. Tanggapan responden mengenai E-Loyalty di PT. X Fitur PT. X dianggap sudah baik, Ada beberapa hal yang dirasa kurang oleh pelanggan dilihat dari indikator reaksi negatif yang dialami saat pelanggan tidak puas.

4. Terdapat pengaruh secara parsial antara E-Service Quality terhadapa E-Loyalty pada pelanggan PT. X Fitur PT. X .

5. Terdapat pengaruh secara parsial antara E-Recovery Service Quality terhadap E-Loyalty pada pelanggan PT. X Fitur PT. X .

6. Terdapat pengaruh secara simultan antara E-Service Quality dan E-Recovery Service Quality terhadap E-Loyalty pada pelanggan PT. X Fitur PT. X.

\section{Acknowledge}

Penulis mengucapkan rasa syukur kepada Allah SWT tanpa kehendak-Nya penulis tidak bisa berdiri hingga sampai dititik ini, serta terimakasih kepada kedua orang tua yang telah merestui, mendoakan dan mendukung cita- cita penulis, pembimbing atas saran dan arahan yang telah diberikan, dan teman- teman yang selalu setia berada disisi penulis dalam suka maupun duka.

\section{Daftar Pustaka}

[1] Anton, T. K. 2014. Keterkaitan E-Service Quality Dan E-Recovery Service Quality Maskapai Penerbangan Air Asia Dengan Menggunakan Structural Equation Modeling. Journal Computech \& Bisnis. Vol.8. No.2.

[2] Parasuranman, Zeithaml, dan Malhotra. 2005. E-S QUAL A Multiple-Item Scale For sesing Electronic Service Quality. Journal Of Service Research. Vol.7. No.10.

[3] Winnie. 2014. The Impact of Trustworthiness and Customer E-Loyalty and E-Satisfaction, International Journal of Academic Research in Business and Social Sciences. Vol.4. Issue 3.

[4] Zehir \& Narcikara. 2016. E-Service Quality and E-Recovery Service Quality Effect on Value Perceptions and Loyalty Intention. Procedia Social and Behavioral Science. 